\title{
Conscientisation in Castalia: A Freirean Reading of Hermann Hesse's The Glass Bead Game
}

\author{
PETER ROBERTS \\ University of Auckland
}

\begin{abstract}
This paper considers Hermann Hesse's novel, The Glass Bead Game, in the light of Paulo Freire's educational philosophy. The Glass Bead Game is set in Castalia, a "pedagogical province" of the $23^{\text {rd }}$ century. It is argued that the central character in the book, Joseph Knecht, undergoes a complex process of conscientisation. Knecht develops an increasingly critical understanding of Castalian society, questioning some of its most cherished assumptions while nonetheless deepening his appreciation of the beauty of the Glass Bead Game. He becomes less certain of his certainties as he grows older, and eventually decides to give away his prestigious post as Magister Ludi (Master of the Glass Bead Game) to pursue a quiet life as a tutor. Dialogue plays a key role in the development of Knecht's critical consciousness. Freirean theory is seen to provide a robust framework for the analysis of key themes in Hesse's text. At the same time, The Glass Bead Game is helpful in demonstrating the meaning and significance of conscientisation and dialogue for educational lives.
\end{abstract}

Keywords: Paulo Freire, Hermann Hesse, Conscientisation, Dialogue, Literature

\section{Introduction}

Paulo Freire wrote primarily as an educational philosopher, political activist and teacher. He was a theorist and a practitioner, not a novelist or dramatist. It would not be unreasonable to claim that Freire's later publications exhibit certain literary qualities. Several of his books were constructed in the form of dialogues (e.g., Freire and Shor, 1987; Horton and Freire, 1990; Freire and Faundez, 1989) or letters (e.g., Freire, 1996, 1998a), and one recently published volume (Freire, 2004) includes a poem Freire wrote in 1971. Even the texts Freire composed in a more traditional academic format during his post-1986 writing period have, at least in some cases (e.g., Freire, 1994, 1997a, 1998b), a more “conversational” tone than most books published by theorists in critical educational studies. Yet, despite these departures from scholarly orthodoxy, it is clear that Freire's primary intention as an author was to develop, convey and discuss his educational ideas via the medium of non-fiction prose. The thinkers to whom Freire has referred in his work have, similarly, been predominantly (but not exclusively) non-fiction writers. Freire's commentators have tended to follow suit, and hundreds of theoretical books and articles on Freirean themes have been published over the past four decades. Among philosophers of 
education in particular, Freire has typically been engaged via the work of other scholars who have read, reflected on and published non-fiction academic writing.

Arguably, however, there is much that might be gained from putting Freirean ideas into conversation with writing of other forms. Freire has sometimes been criticised for the somewhat abstract nature of his written expression. This line of critique has been directed principally at his classic work, Pedagogy of the Oppressed (Freire, 1972a). The criticism becomes less convincing when Pedagogy of the Oppressed is read alongside other books with a strong practical focus (e.g., Freire 1976, 1998a; Freire and Shor, 1987; Horton and Freire, 1990). Nonetheless, even where Freire shows how his ideas might be, or have been, applied in (and developed from) practice, there is often still something missing. We cannot "get inside the heads" of those who think, feel and act out the drama that is their educational lives. The limits of the scholarly form, even as stretched by Freire in his more conversational style, do not allow us to explore the particulars - the circumstances, the interactions, the relationships, the inner workings - of an educational situation or individual life in the manner permitted by some other forms of writing. Novels, by taking us into the hearts and minds of characters, provide an especially helpful means through which to explore the nature and significance of ethical, epistemological and educational ideas for human lives (cf. Nussbaum, 1990, 1995; Katz, 1997; Carr, 2005; Jollimore and Barrios, 2006). Imaginative fiction is, of course, not the only potentially fruitful avenue for this kind of investigation. The medium of film, for example, might serve equally well. But the novel is a form that lends itself particularly well to the exploration of key themes in Freire's philosophy and pedagogy.

One book with special promise in this area is Hermann Hesse's The Glass Bead Game (Hesse, 2000a). Education figures prominently in a number of Hesse's novels (e.g., Hesse, 1968, 1999, 2000b). Hesse also addressed educational questions in some of his short stories (see Hesse, 1974a) and non-fiction writings (Hesse, 1974b, 1978). It is in The Glass Bead Game, however, that his most comprehensive, complex and probing examination of an educational setting occurs. The Glass Bead Game was Hesse's last and longest novel. Hesse agonised over the book, taking more than ten years to complete it (see Field, 1968; Mileck, 1970; Norton, 1976; Remys, 1983). It was first published (as Das Glasperlenspiel) in 1943 and appeared in English translation (originally under the title Magister Ludi) in 1949. Shortly after the publication of the book Hesse was awarded the Nobel Prize for literature. The main part of The Glass Bead Game tells the story of Joseph Knecht, who spends most of his life in Castalia, a "pedagogical province" of the $23^{\text {rd }}$ century. Castalia places a premium on intellectual pursuits, at the centre of which is the Glass Bead Game. The exact workings of the Glass Bead Game in its $23^{\text {rd }}$ century form remain uncertain, but the narrator informs us that the Game is like a universal language: a way of connecting traditions and cultures from both the East and the West and of playing with all disciplines and values. Castalia is a hierarchical society, with students at different levels of schooling and Masters of the various arts. At the summit of the Order of the Glass Bead Game is the Magister Ludi (Master of the Game). Knecht progresses through the school system in Castalia, studies the Game deeply, and is eventually appointed Magister Ludi. He exercises his responsibilities in this position with distinction but as time passes he becomes increasingly critical of Castalia's rigidity, restrictiveness and separation from the rest of the world. Doubts that have been present since his student days find their ultimate expression in his dramatic and 
difficult decision to resign his post as Magister Ludi. He seeks permission from the Board of Educators to leave the Order, and dedicates himself to the task of tutoring Tito, the son of his old friend Plinio. This process barely begins, however, when Knecht dies suddenly while swimming with Tito in an icy mountain lake. The main part of the book is preceded by the narrator's general introduction to the history of the Game, and is followed by thirteen poems and three fictional autobiographies (presented as the posthumous writings of Joseph Knecht).

At the centre of The Glass Bead Game is the educational transformation of Joseph Knecht. But what kind of transformation occurs and how does this come about? Freire's educational philosophy is helpful in addressing this question. Knecht's transformation, it will be argued here, can be seen as a process of conscientisation, through which a dedicated scholar and loyal citizen of Castalia gradually develops an increasingly critical view of the pedagogical province. Dialogue plays a crucial role in shaping Knecht's reflective, questioning orientation toward the world. Freirean theory, I hope to show, allows us to reflect carefully on the nature of Castalian society, appreciate more deeply the experiences of Hesse's characters, and better understand the educational significance of the book. At the same time, Hesse's novel permits aspects of Freire's work to be considered in a fresh light and explored more fully.

\section{The concept of conscientisation}

Conscientisation is one of the best known but most frequently misunderstood aspects of Freire's work. In early publications (Freire, 1972b, 1976), Freire discusses conscientisation - conscientização in the original Portuguese - in relation to different groups within Brazilian society. He describes three modes of consciousness, or ways of thinking and being: magical (semi-intransitive), naïve (transitive) and critical. Magical consciousness prevailed among rural peasant communities, and was characterised by a fatalistic attitude, a lack of historical awareness and a focus on survival. Naïve consciousness was predominant in the urban centres that emerged in Brazil following the Second World War. Its defining features included an emphasis on polemics rather than argument, the oversimplification of problems, and a lack of interest in investigation and dialogue. Critical consciousness was characteristic of "authentically democratic regimes" and included elements such as depth in the interpretation and addressing of problems, the testing of findings and openness to revision, a willingness to accept responsibility, sound argumentation, the practice of dialogue, and acceptance of "what is valid in both old and new" (Freire, 1976, p. 18). Conscientisation consisted in the movement from either magical or naïve consciousness toward critical consciousness. Education, Freire believed, could play a key role in facilitating this process.

This early depiction of different modes of consciousness has been taken by some as an indication that Freire intended conscientisation to be seen in terms of clear-cut, progressive levels or "stages". Removed from its original context, conscientisation has sometimes been applied as a means for describing a process of individual development through fixed, sequential stages of consciousness (e.g., Smith, 1976). As has been argued elsewhere (Roberts, 2000), the "stages" model of conscientisation has some significant epistemological problems. The characterisation of 
conscientisation as a process of “consciousness raising” (e.g., Berger, 1974) leads to further difficulties. This suggests a hierarchy of consciousnesses, ignoring the cultural specificity of different modes of knowing and being. Some ways of understanding the world, it can be argued, are more helpful than others - but only in certain contexts and for particular purposes. The depictions of magical and naïve consciousness were Freire's attempt to capture prevailing patterns of thought and attitudes among different groups of Brazilians during specific periods of that country's history. Freire's focus was not on individuals, and he did not see magical consciousness, naïve consciousness and critical consciousness as pre-defined levels or stages - that is, as universal categories, applicable to all people at all times and in all circumstances. With the enormous interest in Freire's work following the publication of Pedagogy of the Oppressed (Freire, 1972a), conscientisation came to be seen as a kind of "magic bullet": a revolutionary pedagogical "method" capable of eliminating oppression where other approaches had failed. Freire disavowed such readings. He insisted that conscientisation is not a panacea for social ills (Freire, 1998b, p. 55). He stressed that his philosophy and pedagogy could not be reduced to a "method" or even a set of methods (Freire, 1997b). He reinforced the view that conscientisation was a complex, multifaceted, ongoing process, and that it could only be understood in relation to other key concepts in his work such as dialogue and praxis. He emphasised the limits as well as the possibilities in educational initiatives. In the end, frustrated with what he saw as persistent misunderstandings of his intentions, Freire largely abandoned the term "conscientisation". From the late 1970s to the mid 1980s he seldom discussed conscientisation in any detail. In later publications (e.g., Freire, 1996, 1997a, 1998b, 2004), he returned to the concept, this time integrating it with a wider body of theory generated through his dialogical encounters with other scholars such as Ira Shor (Freire and Shor, 1987), Myles Horton (Horton and Freire, 1990) and Antonio Faundez (Freire and Faundez, 1989).

While the notion of conscientisation has been subject to considerable controversy and confusion over the years, some of its key features have been clearly evident from Freire's earliest writings. Conscientisation can be seen as the process of developing a critical consciousness, particularly but not exclusively in relation to social structures, practices and prevailing ideas. The deepening of one's understanding of society through conscientisation involves, among other things, learning to place social problems in their broader contexts, establishing relationships between different phenomena, and appreciating the historical nature of human existence. Conscientisation does not take place through fixed, inevitable, irreversible stages; rather, it occurs as "a process at any given moment" (Freire, 1985, p. 107). Freire does not portray conscientisation in a linear fashion but instead stresses the fluid, dynamic nature of the process. It is not a matter of first developing a critical consciousness, and then engaging in action, and through this bringing about social transformation. In the process of conscientisation reflection and action are necessarily intertwined. For Freire, all aspects of reality are in motion. There is a constant interaction between "consciousness" and "world” (Freire, 1972b). Given this process of incessant change, one can, at best, only come closer to understanding a given object of study (Freire and Shor, 1987). If the "object of study" in the process of conscientisation is the social world, Freire recognises that there is no one legitimate way of comprehending the problems in that world. What conscientisation demands of us is that we strive to deepen and extend our current understanding. This requires the application of intellectual virtues, such as a willingness to question (without assuming 
that everything needs to be questioned all the time), a probing and inquiring stance when faced with a problem, open-mindedness, curiosity, and a certain humility (recognising, among other things, that we cannot "know it all" and that there is always more to learn).

Conscientisation has ontological, epistemological, ethical, and educational dimensions. Conscientisation is, Freire argues, fundamental to our very being as humans. It is "a requirement of our human condition" (Freire, 1998b, p. 55). The form conscientisation takes, however, will differ from one context to another. Developing a critical consciousness involves seeking to know oneself, others and the world. Knowing here, as Freire describes it, is more than mere surface comprehension. It is a process of striving to delve beneath surface appearances, of endeavouring to understand an object of study rigorously. This is not an abstract, purely cognitive process, separated from the rest of the world. Rather, knowing is an intensely practical process, intertwined with the messy realities of everyday life. Knowing, as Freire conceives of it, is something one engages in with one's whole being - with feeling, willing and action as well as with reason (see Freire, 1997a, p. 30). Seeking to know in this manner demands ethical and political commitment. Conscientisation, as the term suggests, involves the cultivation of not just a certain kind of critical awareness but of conscience (Freire, 2004, p. 78). The key to enacting this process in an educational setting, Freire argued, is critical dialogue. Freire argues that as humans we are beings of communication (see Freire, 1976, 1996, 1998b, 2004), and that dialogue is a crucial part of the process of becoming more fully human. Educational dialogue is not mere idle conversation; rather, it is purposeful and rigorous, with a clear sense of structure and direction (see further, Freire and Shor, 1987; Mayo, 1999; Roberts, 2000). Dialogical education focuses on posing and addressing problems rather than giving answers; it draws, and reflects critically, on the knowledge and experience of participants; and it assumes that knowledge is not static but ever evolving (Freire, 1972a). Critical dialogue fosters a better understanding of "self" and "society", enhances the appreciation of "otherness", and allows participants to develop a deeper awareness of themselves as unfinished beings.

\section{Uncertainty, critical thought and social life}

Conscientisation requires a willingness to live with, and indeed embrace, uncertainty. In his later works, Freire spoke often of the need not to become too certain of one's certainties. This does not mean that nothing can be taken as given for particular purposes. Freire acknowledged that we must take certain things for granted in order to make decisions and take action as human beings. Freire's point is that if reality is constantly changing, we too can never completely "stand still"; our understanding of the world must always be open to change. Freire explains:

I have been always engaged with many thoughts concerning the challenges that draw me to this or that issue or to the doubts that make me unquiet. These doubts take me to uncertainties, the only place where it is possible to work toward the necessary provisional certainties. It is not the case that it is impossible to be certain about some things. What is impossible is to be absolutely certain, as if the certainty of today were the same as that of 
yesterday and will continue to be the same as that of tomorrow. (Freire, 1997a, pp. 30-31).

The Glass Bead Game, through the life of Joseph Knecht, demonstrates the importance of uncertainty and critical thought - not just for individuals, but for groups and indeed whole societies. Castalia, Hesse's novel shows, is in a state of decay as a society precisely because most of its citizens fail to question its structures, its system of education, and its superiority over other societies. The hierarchical nature of Castalian society encourages order and conformity. Castalians have little respect for history, and while they believe themselves to have gone beyond the follies of the Feuilleton Age (the first half of the $20^{\text {th }}$ century), they have not learned from some of the mistakes made in that period. They are, in Freirean terms, too certain of their certainties. They seek to uphold some traditions but abandon others too quickly. They do not have, as Freire puts it, either a willingness to consider the new or the good sense not to abandon the old just because it is old (Freire, 1976, p. 18). When faced with challenges, many Castalians withdraw further into the protective confines of the pedagogical province or respond with coldness and incomprehension. Those within the Order who do not conform lead a precarious existence (as is the case with Tegularius, Joseph's over-sensitive but brilliant friend), and are sometimes treated with outright contempt and brutality (as occurs with Bertram, the deputy of the Magister Ludi in office just prior to Knecht's investiture: see Friedrichsmeyer, 1974).

In some important respects, Castalia provides largely unfriendly soil for the cultivation of a critical mode of being. There is, as Durrani (1982) argues, a naïve quality to some of the analytical statements by even the most admirable characters. The Music Master is perhaps the most striking example:

It is beyond doubt ... that in the Magister Musicae Hesse has created a good, almost a saintly figure. In his serenity, his goodwill towards Knecht, and his unpretentious devotion to art, he appeals to the reader as an emblem of all that is best in the province. But although he may be above criticism as a human being, it is equally true that he is naively optimistic about the organization to which he belongs, and blind to its defects. (p. 660)

Knecht constitutes an exception to the rule in Castalia (Swales, 1978; Roberts, 2008/in press). This does not mean that the pedagogical province has played no role in the cultivation of his critical consciousness. Castalia plays a part in providing the culture of intellectual discipline necessary for carefully structured, in-depth reflection. Knecht learns through his involvement with the Glass Bead Game and his interactions with other Castalians the value of reasoning, deliberation and contemplation. Reflective reasoning allows him to make the unprecedented decision to relinquish his role as Magister Ludi and to leave the Order of the Glass Bead Game. Knecht's Circular Letter to the Board of Educators, in which he requests permission to leave and outlines his reasons for doing so, is, in many respects, a model of thoughtful, carefully constructed argument. That said, Knecht's analysis of Castalia's limits also has its own limits. His critique of Castalian hierarchy lacks a theory - or at least a well articulated theory - of power or politics. Little is said about the sexism inherent in the Castalian system. Castalia is not merely a hierarchy but a male hierarchy, and Knecht fails to render this problematic. Knecht wishes to bridge the two spheres - the hermetically sealed "inner" world of Castalia and the wider outside world - but he has 
only a vaguely formed and somewhat romantic idea of what life in the outside world entails.

Knecht, then, may remove himself from Castalia, but Castalia continues to "live through" him. He has, in Freirean terms, been conditioned but not determined by his context (Freire, 1998b, p. 26). The structures, practices, attitudes and ideas that characterise the pedagogical province play their part in making Knecht the man that he becomes, but he cannot be reduced to merely the sum of these influences. Hesse placed supreme importance on the integrity of the individual (see Hesse, 1974b, 1978), and The Glass Bead Game is, among other things, a critique of the tendency in social systems to suppress individuality. At the same time, Hesse recognised that we are social and historical beings, and his portrait of Knecht is consistent with this (cf. Wilde, 1999). Knecht cannot shed the dominant influence of Castalia on his life - on his mode of thinking and being - and yet he is not merely Castalian. Knecht's conscientisation involves, among other things, the gradual deepening of his understanding of the relationship between "self" and "society". Knecht's growing consciousness of himself is, as Cohn (1950) points out, a key theme in the novel. But this is a consciousness of himself with others. Castalia may have been the dominant influence on Knecht's life, but others who represent and carry with them the outside world - Plinio Designori and Father Jacobus - also play pivotal roles in making him the man that he becomes. The next section elaborates on how and why this is so.

\section{The role of dialogue}

Dialogue plays an important pedagogical role in the development of Knecht's critical consciousness and is one of the defining characteristics of his relationships with Plinio Designori and Father Jacobus. Joseph's first encounter with Plinio is at Waldzell. Only the brightest of the elite students in Castalia attend the school at Waldzell. Waldzell is the home of the Glass Bead Game, and it is here that the Magister Ludi resides. Plinio is a youth from a prominent family outside Castalia who is sent to Waldzell to experience the unique intellectual stimulation and learning provided by the pedagogical province. Not long after encountering Plinio, Joseph senses that "this other boy would mean something important to him, perhaps something fine, an enlargement of his horizon, insight or illumination, perhaps also temptation and danger” (Hesse, 2000a, p. 86). Plinio and Joseph begin what will become a lifelong friendship. They become the key protagonists in a series of vigorous debates over the strengths and weaknesses of the Castalian system. Plinio attacks the pedagogical province while Knecht defends Castalian ideals. In their debates, Plinio and Joseph exhibit many of the qualities of Freirean dialogue. They enter into their exchanges with a searching, probing, questioning frame of mind; they demonstrate an ability to challenge as well as to be challenged; and they deepen and extend their views through interaction with each other. While their early exchanges are characterised by youthful exuberance and enthusiasm, qualities such as humility and tolerance come more to the fore with time and the advancement of years. There is at first a sort of battle of wills and ideas, but this later becomes, for some of the time at least, more a demonstration of profound respect and a willingness to listen to and learn from each other.

When the two protagonists meet again after being separated for many years, there is a certain weariness in both of them. Plinio is weighed down by his political and family 
responsibilities, while Knecht is burdened with his duties as Magister Ludi. Knecht appears to adopt a somewhat condescending air in his conversation with Plinio. Plinio seems to be reaching out to him, seeking to establish a stronger emotional connection with his friend, but the Magister Ludi responds in a disarmingly "cheerful" manner. He listens carefully to what Plinio has to say; yet he seems at this point to be still too much the representative of Castalia, rather than Joseph the human being. Listening, as Freire sees it, is an important part of genuine dialogue. It is "a permanent attitude on the part of the subject who is listening, of being open to the word of the other, to the gesture of the other, to the differences of the other" (Freire 1998b, p. 107). This is not merely a rational but also an emotional process. Plinio cannot understand Knecht's apparent amusement in the face of a heartfelt confession from an old friend. At first glance, it is almost as if the detachment typical of the Castalian hierarchy cannot avoid seeping into Knecht, despite his clear differences with other members of the Order. Plinio, as an outsider, experiences this more acutely than others who come into contact with Knecht. Knecht responds, however, by saying: “... if I do not go along with your sadness ..., that does not mean I don't recognize it or take it seriously” (Hesse 2000a, p. 293). As the dialogue continues, the two friends consider their differences as well as similarities and reflect on their earlier encounters. Knecht is about to make the momentous decision to resign his position as Magister Ludi and he too seeks to strengthen his emotional bond with Plinio - but in his own distinctive way, with "cheerful serenity ... even in unhappiness and suffering” (p. 300).

Knecht's relationship with Father Jacobus also plays a pivotal role in his subsequent development. Knecht is sent by the Castalian authorities on a mission to a Benedictine monastery in Mariafels. Father Jacobus is one of the monastery's most respected figures, and Knecht develops a strong intellectual admiration for him. During his stay at the monastery, Joseph learns that he and Jacobus share an interest in the work of a teacher, Johann Albrecht Bengel. They engage in a critical but cheerful dialogue about Bengel, "a fruitful conversation, out of which sprang mutual understanding and a kind of friendship” (Hesse, 2000a, p. 154). As Knecht's relationship with Father Jacobus grows and matures, the respect between the two men deepens:

Jacobus enjoyed the exchange of views with so well trained yet still so supple a young mind; this was a pleasure he did not often have. And Knecht found his association with the historian, and the education Jacobus provided, a new stage on the path of awakening - that path which he nowadays identified as his life. (p. 155)

What does Knecht learn from Father Jacobus? The narrator's answer is that "he learned history" (p. 155). "He learned the laws and contradictions of historical studies and historiography. And beyond that, in the following years he learned to see the present and his own life as historical realities” (p. 155). Arguably, however, Knecht learns much more than this from his relationship with Jacobus. He sharpens his awareness of some of the limits of Castalian society, laying the foundations of the argument that will later underpin his Circular Letter to the Board of Educators; he develops a more nuanced view of his own strengths and weaknesses; and, importantly, he learns the value of dialogue at both an individual and societal level. Knecht's dialogue with Father Jacobus provides the basis for a better relationship - 
one of greater trust, improved communication and sounder understanding - between Castalia and the Catholic Church.

Joseph and Jacobus change as individuals through their dialogical encounters. Near the beginning of their relationship, Father Jacobus approaches their conversations with a certain aggressiveness. Indeed, there is a degree of close-mindedness in his stance. Jacobus adopts a reactionary posture, making belittling remarks about Castalia and responding to Knecht in at times thunderous tones (pp. 155-156). He has spells of "angry unfairness" (p. 158). He lacks, in Freirean terms, the humility and the open-mindedness necessary to engage fully in educational dialogue. At first, he sees virtually nothing of value in the pedagogical province:

Whenever he found something objectionable in Knecht's way of thinking, he blamed it on that "modern" Castalian spirit with its abstruseness and its fondness for frivolous abstractions. And whenever Knecht surprised him by wholesome views and remarks akin to his own thought, he exulted because his young friend's sound nature had so well withstood the damage of Castalian education. (p. 155)

Despite his youth, Joseph displays a calmness and an equanimity that is, in the earlier stages of their relationship, sometimes lacking in the older man. Yet, on a number of philosophical and historical matters, Knecht cannot deny the power of Jacobus's reasoning. He is encouraged, in part by the initial ferocity of Jacobus's attacks, to probe his own assumptions further and to ask more searching questions of the Castalian way of life than would have been possible on his own. Father Jacobus, while too quickly dismissive of Castalia in his early conversations with Knecht, remains modest about his own achievements. Knecht speaks with him simply as a fellow scholar, a colleague in the pursuit of truth. He is at first unaware of Father Jacobus's standing as a man of the highest reputation, constantly in demand for advice, "someone who was consciously participating in world history, and helping to shape it as the leading statesman of his Order" (p. 158). Father Jacobus, like Knecht, values dialogue for its own sake as well as for the learning it facilitates. Both Jacobus and Knecht love the very process of mutual inquiry, of exchanging views and testing one's ideas in the company of another. Over time, Father Jacobus comes to appreciate that Castalia and the Church are perhaps not so far apart as he had hitherto imagined.

Hesse's novel allows us to see more clearly how Freirean dialogue "works” in a wider educational context. It does not do so, however, in a didactic or mechanical fashion. The three key participants in the dialogues that play such an important role in Knecht's life - Plinio, Father Jacobus and Knecht himself - are all complex, multilayered, sometimes contradictory human beings. They have character flaws as well as strengths, and these have a bearing on the nature of their exchanges. At times, their conversations have an anti-dialogical character, with one or both of the participants lacking in the humility, openness or willingness to listen and learn necessary for genuine Freirean dialogue. Importantly, the book shows how context and experience impact on the content, tone and consequences of dialogue. Knecht, Jacobus and Plinio have all enjoyed certain privileges. Knecht and Jacobus have been "protected" from some of the demands of the outside world by their respective Orders (Knecht more so than Jacobus), and Plinio has been fortunate enough to have come 
from a wealthy family. Their individual backgrounds, to varying degrees and in different ways, set limits on their thinking as they enter into their conversations with others. Yet, through dialogue, something more than the mere combination of their respective views emerges. Knecht, Jacobus and Plinio change as their conversations progress. In all three cases, their view of Castalia deepens; all three, in distinctive ways given their different positions, come to view the pedagogical province in a more critical, balanced and mature light.

\section{Conscientisation and the non-neutrality of education}

The analysis to this point begs the question: what is the basis on which Knecht's views (and those of Plinio and Father Jacobus) might be said to be "more critical, balanced and mature"? Against what criteria can such judgements be made? This is important not just in understanding Knecht's transformation in The Glass Bead Game but in addressing some of the epistemological assumptions underlying Freire's approach to dialogue and conscientisation. Gert Biesta's work on the "impossibility of education” (Biesta, 1998, 2005) is helpful in addressing this point. The impossibility of education, Biesta argues, lies in its unpredictability. Education cannot be reduced to mere technique or to a process of teachers moulding students. In thinking about education we must take into account the ways in which students "use" what is presented by the teacher. It is this "use" of what is presented that makes education possible - but also unpredictable (1998, pp. 503-504). This has implications for critical pedagogy:

If it is the case that the very possibility of education is sustained by its impossibility, then it follows that the idea of critical pedagogy as a positive program and project is problematic for two different reason[s]. First, because such a program can only be successful if it is able to control the 'use' of what it tries to achieve. [...] Second, because such a program would eventually imply an erasure of the political realm, of the realm where the risk of disclosure is a possibility. This is the main danger implied in the normalizing tendency of critical pedagogy. (p.504)

For Biesta, the only way for critical pedagogy to proceed, if it is to maintain pedagogical and political consistency, is to perpetually challenge all claims to authority, including those made by critical pedagogy itself (p. 505). Such a challenge cannot be mounted in the name of "some superior knowledge or privileged vision" but can only proceed, Biesta suggests, on the basis of a "fundamental ignorance" (p. 505). Biesta elaborates:

Such ignorance is neither naiveté nor skepticism. It just is an ignorance that does not claim to know how the future will be or will have to be. It is an ignorance that does not show the way, but only issues an invitation to set out on the journey. It is an ignorance that does not say what to think of it, but only asks, 'What do you think about it?' In short, it is an ignorance that makes room for the possibility of disclosure. It is, therefore, an emancipatory ignorance. (p. 505) 
Biesta notes that this seems to contradict a key tenet in the critical tradition, namely, the idea that "emancipation can be brought about when people have an adequate understanding of, if not simply the plain truth, about their own situation” (p. 505). Biesta's response is not to deny that change is possible or to see knowledge as futile. Instead, his approach "signifies the end of the 'innocence' of knowledge as a critical instrument, and thus the end of the possibility of demystification. It urges us to recognize that we are always operating in a field of power/knowledge against power/knowledge" (p. 506). Biesta advances a notion of "counter-practice”, a form of transgression as "the experimental illumination of limits" (p. 507). He concludes:

A counter-practice should not be designed out of an arrogance that it will be better (or that one claims to know that it will be better; once again: ignorance) than what exists. A counter-practice is only different. The critical task of a counter-practice can therefore only be to show (to prove, Foucault says) that the way things were was only one (limited) possibility. But this step is crucial, as it opens up the possibility 'of no longer being, doing, or thinking what we are, do, or think'. (p.507)

This provides an intriguing standpoint from which to reconsider Freirean philosophical assumptions and Knecht's process of conscientisation. Biesta's notion of "emancipatory ignorance" bears some resemblance to the Freirean idea of uncertainty. Uncertainty, from Freire's point of view, is ethically desirable, as is the kind of ignorance promoted by Biesta. Uncertainty provides the "motor", or impetus, for questioning and ongoing critical thought. Being prepared to not only live with but embrace uncertainty affirms our existence as curious, inquiring beings. Uncertainty on its own does not constitute critical consciousness (in the Freirean sense), but it is essential for it. Biesta's suggestion that emancipatory ignorance "does not show the way, but only issues an invitation to set out on the journey" is also largely consistent with Freirean theory and Knecht's educational path in The Glass Bead Game. Freire states emphatically that it is not his job as an educator to impose his political views on students; rather, his role is to provide the conditions for students to investigate matters of political significance themselves (see Freire's comments in Escobar et al., 1994). Teachers, he insists, have a responsibility to not only allow but actively encourage the consideration of ethical and political alternatives. The educational imperative, if it might be stated in those terms, is to make such a journey matter for students. The point is not to prescribe (or proscribe) answers but to foster an educational environment where students will learn how to ask questions. This, from a Freirean perspective, is where an important element in the non-neutrality of education lies: the favouring of some pedagogical dispositions - e.g., a willingness to question, to inquire and to engage in dialogue - over others. These are the qualities Joseph Knecht develops in his process of conscientisation, and they distinguish him from some of his colleagues in Castalia. Biesta, it seems to me, also presupposes a form of non-neutrality in his work, inasmuch as he favours (for instance) the possibility of disclosure, the value of interrogating our presuppositions about power/knowledge, and the very idea of inviting students to set out on an educational journey.

Biesta claims that a counter-practice should be only different, not better. Freire seems to suggest, however, that conscientisation involves the development of a mode of thinking and being that is preferable over some other ways of thinking and being. A searching, questioning, probing, investigative, dialogical, critical approach to 
understanding and living in the world, Freire implies, is better than, say, a passive, unquestioning, monological orientation. From this perspective, it might be said that Knecht, Plinio and Jacobus all develop a "better" - more "critical, balanced and mature" - understanding of the world through their dialogical relationships with each other. Freire argues against political prescriptiveness in educational settings but he is not an epistemological or ethical relativist. Biesta cautions against the idea of believing we can or should "demystify" the world for others. Freire does not want teachers to assume they have a right or a responsibility to clear away clouds of student ignorance; on the other hand, he also does not want teachers to pretend they have nothing of value to offer students in assisting them to learn. Teachers have an important role to play in allowing students to see, in Biesta's terms, that the way things are is not the only way they could be. This is made more possible by some pedagogical approaches than others. For example, if teachers were to encourage students to adopt or investigate just one view on a contentious social issue, when they are aware of well developed competing views, they would be at odds with the Freirean imperative to foster exploration of alternatives. The Castalian education system does not prohibit students from investigating alternatives but neither does it actively encourage them to do so. Knecht, through his dialogues with Plinio and Father Jacobus, as well through his own studies and reflections, comes to believe that many of his fellow Castalians are too narrow and rigid in their view of themselves, their society, and the lives of others in the outside world. Knecht's conscientisation does not, however, lead him to reject all he has learned in the pedagogical province. To the contrary; Knecht, by being prepared to ask questions, to probe further than most of his classmates and many of the Masters, and to enter into debates with Plinio and Jacobus, comes to appreciate more deeply the aesthetic richness and complexity of the Glass Bead Game. Knecht does not, by the time he is ready to leave his position as Magister Ludi, see himself as having 'demystified' Castalia. He has formed a more critical view of the pedagogical province, but he has also developed a greater awareness of his own limits and of the need for ongoing reflection, dialogue and action. This idea is developed more fully in the next section.

\section{Conscientisation: an ongoing process}

A key element in Knecht's conscientisation is his growing awareness of himself as an unfinished human being. Knecht has a maturity beyond his years. He is an exemplary student and scholar, a fine administrator, a respected figure among his peers (at all stages of his life), a thoughtful and caring person, and a brilliant exponent of the Glass Bead Game. He reaches the very summit of the Castalian hierarchy with his appointment, at a comparatively young age, as Magister Ludi. He has honesty and integrity, and abhors nastiness when he observes this in others. In his Magisterial duties, he carries himself with dignity and poise. In many ways, he lives the ideal Castalian life, fulfilling his calling to greatness within the pedagogical province. And yet, Knecht's decision to leave Castalia is made with a profound awareness that he has much more to achieve. In this respect, he exhibits one of the key characteristics of conscientisation: an awareness of our unfinishedness as human beings and of the ethical implications arising from this (see Freire, 1998b, p. 55). In his tenure as Magister Ludi Knecht had come to value, more and more, the process of teaching, finding his work with younger students especially rewarding. This, he comes to believe, is where his key contribution lies. He leaves Castalia with a renewed sense 
of freedom - an open embracing of uncertainty - and a new appreciation for the beauty of the day and the world. He has hope for the future and is filled with a quiet excitement about the challenges that lie ahead in his new role as a tutor for Tito, Plinio's son. He has come to realise that there is a whole new world outside Castalia, vibrant and complex, waiting to be explored:

Life in the world, as the Castalian sees it, is something backward and inferior, a life of disorder and crudity, of passions and distractions, devoid of all that is beautiful or desirable. But the world and its life was in fact infinitely vaster and richer than the notions a Castalian has of it; it was full of change, history, struggles, and eternally new beginnings. It might be chaotic, but it was the home and native soil of all destinies, all exaltations, all arts, all humanity; it had produced languages, peoples, governments, cultures; it has also produced us and our Castalia and would see all these things perish again, and yet survive. My teacher Jacobus had kindled in me a love for this world which was forever growing and seeking nourishment. But in Castalia there was nothing to nourish it. Here we were outside of the world; we ourselves were a small, perfect world, but one no longer changing, no longer growing (Hesse, 2000a, pp. 378-379).

Knecht, then, by his own assessment, remains incomplete and is eager to continue his growth as a human being. This focus on incompleteness was arguably both a deliberate decision on the part of Hesse as author and a reflection of Hesse the man on his own path of spiritual and intellectual development. There was a certain unity in Hesse's life, as there was in Knecht's, and the same themes find expression, in different ways, again and again in his writing. But while The Glass Bead Game was Hesse's last novel, and in this limited sense brought his work to a close, he continued to read, write and reflect until his death at the age of eighty five. Hesse, like Knecht, could only ever find relative and temporary stability. He was always, as Freire would have put it, a restless being, constantly curious, always striving to know more (cf. Freire, 1985). Hesse felt from an early age that for him it was to be "a poet or nothing at all” (Helt, 1996), just as it seemed for Joseph Knecht to be Castalia or nothing at all. Hesse may have gone through more overt trials in his school days and experienced greater difficulty in dealing with an authoritarian system of education than appeared to be the case with Joseph. And while Hesse's relationship with his parents was to leave its imprint on a number of his writings, Joseph's parents may have died while he was still very young (the narrator leaves some uncertainty on this point). But the seeds of change - of not simply accepting what tradition and authority had decreed - were planted for both Hesse and Knecht before they had emerged into full adulthood, and these were to grow and take more robust form in the decades that followed. Hesse experienced periods of serious depression and even despair throughout his life (see Mileck, 1978). He turned to the spiritual teachings of the East (while also not ignoring the religious traditions of the West), aestheticism and psychoanalysis for answers to the questions being posed in his restless mind. And while the last third of his long life was in many ways more settled than his earlier years, there was never a point at which he declared or seemed to feel that he could be fully content, fully at rest, completed. This, I believe, is what he wanted to convey in the book (and this view was very much shared by Freire): all of us remain incomplete; we go to our graves never having realised all we might have achieved, sometimes 
with a mixture of pride and regret, but always with further questions and more work to do.

\section{Concluding comments}

In his later publications (e.g., Freire, 1994, 1997b, 1998a, 1998b, 2004) Freire stressed the need to keep "reinventing" his work. This process demands that we not forget the circumstances under which Freire's books were authored, and that we attempt to come as close as possible to understanding the deeper meaning behind his texts, while also accepting that other contexts and situations require new readings, different methods, and fresh applications of his ideas. This paper has been completed in this spirit of "reinventing" Freire by applying key elements of his theoretical framework to Hermann Hesse's The Glass Bead Game. The central character in Hesse's novel, Joseph Knecht, undergoes a gradual but profound process of educational transformation. Knecht's conscientisation mirrors many of the features of Freire's educational ideal. He develops a critical, questioning frame of mind, becoming "less certain of his certainties" as he grows older, and this leads to his eventual decision to resign his post as Magister Ludi. Knecht's dialogical relationships with other key characters play a key role in this process. He feels an increasingly strong need to teach - to play a role in shaping and guiding young people, not just within but beyond the pedagogical province. This distinguishes him from most of his fellow Castalians, who see themselves as separate from and superior to the rest of world. Castalia remains a closed, inward-looking, rigid hierarchy, and Knecht struggles against this. At the end of the main part of the novel, Knecht remains an incomplete being, and is aware of himself as such. His sudden death brings his personal quest to a premature close, but it is clear that the educational process he has started will continue with Tito and others.

It should be noted, in closing, that this is only one of the books by Hermann Hesse that lends itself readily to Freirean analysis. Several of Hesse's other novels particularly, but not exclusively, Beneath the Wheel (Hesse, 1968a) and Siddhartha (Hesse, 2000b) - could also be examined fruitfully from a Freirean point of view. There are, moreover, strong connections that can be drawn between Freire and other literary figures. Dostoevsky, with his searching exploration of philosophical themes in works such as The Brothers Karamazov, is one writer who stands out here (see Roberts, 2005), but there are many others who offer rich possibilities for analysis. For educational philosophers (and not just those concerned with Freire), the list of novelists who might prove helpful is extensive. Leo Tolstoy, George Eliot, Virginia Woolf, Franz Kafka, Albert Camus, Jean Paul Sartre, Chinua Achebe, Iris Murdoch, Milan Kundera, Umberto Eco, Margaret Atwood, and Ben Okri, to name a few, have all, in different ways, addressed complex ethical, epistemological and ontological dilemmas - with important implications for education - in their novels. By putting educational theorists into conversation with novelists - or the characters they create light can be shed on both genres of written work. Academic books permit the systematic, reasoned, coherent development of educational ideas; novels, or at least some novels, allow us to see how these ideas can be "lived out" in the thoughts, feelings, actions, relationships, and experiences of characters. This paper has made only a modest beginning in this area, and there is considerable scope for further work of this kind. 


\section{Acknowledgement}

I wish to thank Gert Biesta for his very helpful comments on an earlier version of this paper.

\section{References}

Berger, P. (1974). Pyramids of sacrifice: Political ethics and social change. New York: Basic Books.

Biesta, G. (1998). Say you want a revolution ... Suggestions for the impossible future of critical pedagogy, Educational Theory, 48, 499-510.

Biesta, G. (2005). What can critical pedagogy learn from postmodernism? Further reflections on the impossible future of critical pedagogy. In I. Gur-Ze'ev (Ed.) Critical theory and critical pedagogy today: Toward a new critical language in education. Haifa: Studies in Education, University of Haifa.

Carr, D. (2005). On the contribution of literature and the arts to the educational cultivation of moral virtue, feeling and emotion. Journal of Moral Education, 34, 137-151.

Cohn, H.D. (1950). The symbolic end of Hermann Hesse’s ‘Glasperlenspiel'. Modern Language Quarterly, 11, 347-357.

Durrani, O. (1982). Hermann Hesse’s Castalia: Republic of scholars or police state? Modern Language Review, 77, 655-669.

Escobar, M., Fernandez, A.L., Guevara-Niebla, G. \& Freire, P. (1994). Paulo Freire on higher education: A dialogue at the National University of Mexico. Albany, NY: State University of New York Press.

Field, G.W. (1968). On the genesis of the Glasperlenspiel. The German Quarterly, $41,673-688$.

Freire, P. (1972a). Pedagogy of the oppressed. Harmondsworth: Penguin.

Freire, P. (1972b). Cultural action for freedom. Harmondsworth: Penguin.

Freire, P. (1976). Education: The practice of freedom. London: Writers and Readers.

Freire, P. (1985). The politics of education. London: MacMillan.

Freire, P. (1994). Pedagogy of hope. New York: Continuum. 
Freire, P. (1996). Letters to Cristina: Reflections on my life and work. London: Routledge.

Freire, P. (1997a). Pedagogy of the heart. New York: Continuum.

Freire, P. (1997b). A response. In P. Freire, J.W. Fraser, D. Macedo, T. McKinnon, \& W.T. Stokes (Eds.) Mentoring the mentor: A critical dialogue with Paulo Freire. New York: Peter Lang.

Freire, P. (1998a). Teachers as cultural workers: Letters to those who dare teach. Boulder, Colorado: Westview Press.

Freire, P. (1998b). Pedagogy of freedom: Ethics, democracy, and civic courage. Lanham, Maryland: Rowman and Littlefield.

Freire, P. (2004). Pedagogy of indignation. Boulder and London: Paradigm.

Freire, P. \& Faundez, A. (1989). Learning to question: A pedagogy of liberation. Geneva: World Council of Churches.

Freire, P. \& Macedo, D. (1987). Literacy: Reading the word and the world. London: Routledge.

Freire, P. \& Shor, I. (1987). A pedagogy for liberation. London: MacMillan.

Friedrichsmeyer, E. (1974). The Bertram episode in Hesse’s Glass Bead Game. The Germanic Review, 49, 284-297.

Helt, R.C. (1996). '... A poet or nothing at all': The Tübingen and Basel years of Hermann Hesse. Providence, RI: Berghahn Books.

Hesse, H. (1968). Beneath the wheel (M. Roloff, Trans.). New York: Picador. (Original work published 1906)

Hesse, H. (1974a). Stories of five decades (R. Manheim, Trans., with two stories translated by D. Lindley, T. Ziolkowski, Ed.). Frogmore, St Alban’s, Herts: Triad/Panther.

Hesse, H. (1974b). Reflections (selected from his books and letters by V. Michels, R. Manheim, Trans.). New York: Farrar, Straus and Giroux.

Hesse, H. (1978). My belief: Essays on life and art (D. Lindley, Trans., with two essays translated by R. Manheim, T. Ziolkowski, Ed.). London: Triad/Panther.

Hesse, H. (1999). Demian (M. Roloff \& M. Lebeck, Trans., T. Mann, Introduction). New York: Perennial Classics. (Original work published 1919)

Hesse, H. (2000a). The Glass Bead Game (R. Winston \& C. Winston, Trans.). London: Vintage. (Original work published 1943) 
Hesse, H. (2000b). Siddhartha (S.C. Kohn, Trans., P.W. Morris, Introduction). Boston: Shambhala. (Original work published 1922)

Horton, M. \& Freire, P. (1990). We make the road by walking: Conversations on education and social change. Philadelphia: Temple University Press.

Jollimore, T. \& Barrios, S. (2006). Creating cosmopolitans: the case for literature. Studies in Philosophy and Education, 25, 263-283.

Katz, M. (1997). On becoming a teacher: May Sarton's The Small Room. Philosophy of Education 1997. Urbana-Champaign: Philosophy of Education Society. Retrieved October 29, 2001 from http://w3.ed.uiuc.edu/EPS/PESYearbook/97_docs/katz.html

Mayo, P. (1999). Gramsci, Freire and adult education: Possibilities for transformative action. London: Zed Books.

Mileck, J. (1970). Das Glasperlenspiel: Genesis, manuscripts, and history of publication. The German Quarterly, 43, 55-83.

Mileck, J. (1978). Hermann Hesse: Life and art. Berkeley: University of California Press.

Norton, R.C. (1973). Hermann Hesse's futuristic idealism: The Glass Bead Game and its predecessors. Bern, Switzerland: Herbert Lang \& Frankfurt/M., WestGermany, Peter Lang.

Nussbaum, M. (1990). Love's knowledge: Essays on philosophy and literature. New York: Oxford University Press.

Nussbaum, M. (1995). Poetic justice: The literary imagination and public life. Boston, Mass.: Beacon Press.

Remys, E. (1983). Hermann Hesse's Das Glasperlenspiel: A concealed defense of the mother world. New York: Peter Lang.

Roberts, P. (2000). Education, literacy, and humanization: Exploring the work of Paulo Freire. Westport, CT: Bergin and Garvey.

Roberts, P. (2005). Freire and Dostoevsky: Uncertainty, dialogue and transformation. Journal of Transformative Education, 3, 126-139.

Roberts, P. (2008/in press). More than a metaphor: The education of Joseph Knecht. Pedagogy, Culture and Society, 16.

Smith, W. (1976). The meaning of conscientizacao: The goal of Paulo Freire's pedagogy. Amherst, MA: Center for International Education.

Swales, M. (1978). The German Bildungsroman from Wieland to Hesse. Princeton, N.J.: Princeton University Press. 
Wilde, L. (1999). The radical appeal of Hermann Hesse's alternative community. Utopian Studies, 10, 86-97. 